\title{
Postfotografija: Lietuvos fotografijos evoliucijos akligatvis ar tarpinè grandis?
}

\section{Jurijus Dobriakovas}

Fotografijos ir medijos meno katedra

Vilniaus dailès akademija

Maironio g. 6, LT-01124 Vilnius

jurij.dobriakov@vda.lt

$2006 \mathrm{~m}$. Lietuvos meno lauke iškilo ir gana greitai ịsitvirtino bei aštrias diskusijas paskatino naujas terminas - postfotografija. Jaunosios kartos menotyrininkų, kuratorių ir menininkų pradètas postfotografijos sąjūdis siekè kritiškai dekonstruoti institucinę fotografijos sistemą, paviešinti jos dogmas bei praplèsti fotografinès raiškos ir diskurso ribas šiuolaikinio meno kontekste. Tačiau šio reiškinio aktualumas Lietuvoje buvo trumpalaikis - sumažèjus domèjimuisi atskirų medijų problemika, po $2010 \mathrm{~m}$. fotografijos aktualiju svarstymuose postfotografijos sąvoka vartota retai. Vis dèlto kritinis požiūris į fotografiją visiškai neišnyko, nes šiuolaikinio meno kūrejjai fotografines priemones tebenaudoja ịvairiomis nekonvencinėmis formomis. Todèl prasidedant XXI a. 3-iajam dešimtmečiui atrodo svarbu apsvarstyti ir apibendrinti postfotografijos idejjų reikšmę ir poveikio mastą Lietuvoje.

Reikšminiai žodžiai: postfotografija, išplèstinè fotografija, šiuolaikinè fotografija, medijų menas, šiuolaikinis menas. 
Be kitų dalyku, $2006 \mathrm{~m}$. Lietuvos fotografijos ir šiuolaikinio meno istorijai reikšmingi tuo, kad viešai pirmą kartą pasirodė ir išplito nauja paradigmini lūži rodanti ar bent žadanti postfotografijos sąvoka. Šis iš tarptautinio diskurso paimtas terminas ir reiškinys igijo formą pirmiausia tụ metų rudeni bendraminčiu menininkų, menotyrininkų ir kuratoriu grupės surengtoje parodoje komentarai@3xpozicija.lt: postfotografinès büsenos šiuolaikiniame mene Lietuvos fotomenininku sajungos „Prospekto“ galerijoje bei jos viešame kuravimo procese specialiai tam sukurtame tinklaraštyje 3xpozicija.lt ir vienu metu su paroda pasirodžiusiame teminiame LFS žurnalo Fotografija numeryje Postfotografija ${ }^{1} .2007 \mathrm{~m}$. jis prasitęse 3xpozicija.lt bendruomenès projekte bei leidinyje Fotografijos, istorijos, žemèlapiai: foto/karto/istorio/grafijos (kuratoriai ir sudarytojai - Vytautas Michelkevičius, Agnė Narušytė, Lina Michelkevičè), nors šio projekto apimtis buvo kiek siauresnè: meninis Lietuvos fotografijos istorijos rašymo galimybiu tyrimas ir žemėlapiavimas. Iš dalies postfotografijos sričiai priklauso ir keli vèlesni (2007; 2008) Fotografijos numeriai, kuriuos sudarė Margarita Matulytė, Julija Fomina ir Valentinas Klimašauskas', taip pat paroda Lietuvos daile '08: Fotografija (ŠMC, 2008, ypač J. Fominos ir V. Klimašausko kuruota dalis Kai vaizdas tampa pokalbiu). Kitas ideologiškai artimas reiškinys, gyvavęs Klaipėdoje 2004-2010 m., yra fotografijos ir paralelinių meno formų bienalė Erozija, pradèta Klaipèdos kultūrų komunikacijų centro direktoriaus Igno Kazakevičiaus ir fotografo Remigijaus Treigio, vèliau kuruota dabartinio (nuo 2020) Lietuvos fotomenininku sajungos pirmininko, menininko ir kuratoriaus Gyčio Skudžinsko. Visuose šiuose renginiuose ir procesuose dalyvavo neformali, tačiau studijų patirties, asmeninių draugysčių, amžiaus kategorijos ar panašiu kūrybinių ir teorinių interesų susaistyta jaunosios kartos menininkų bendruomenė, kurios nemažai daliai rūpėjo ir platesnè (naujujų) medijų kultūra - pastaroji aplinkybė svarbi apmąstant postfotografijos sampratos atsiradimą ir raidos dèsningumus Lietuvos meno lauke.

Minèta bendruomenè savo iniciatyvas pirmiausia priešino ilgą laiką ryškiausiu ir vyraujančiu Lietuvos fotografijos reiškiniu buvusiai dar XX a. 7-ajame dešimtmetyje įtvirtintai ir instituciškai įteisintai humanistinei Lietuvos fotografijos mokyklai, nors šiuolaikinės fotografijos tyrèjai

1 Postfotografija, 2006, Nr. 2 (13), sud. Vytautas Michelkevičius.

2 [re:] Fotografija, 2007, Nr. 1 (14), sud. Margarita Matulytė; Nr. 2 (15), sud. Margarita Matulytė; Fotografija, 2008, Nr. 1-2 (16-17), sud. Julija Fomina ir Valentinas Klimašauskas.

3 Interviu, 2008, Nr. 11/12, sud. Linara Dovydaitytè ir Simon Rees. 
A. Narušytè, M. Matulytė ir V. Michelkevičius pažymi, kad anksčiausiai XX a. 9-ajame dešimtmetyje Lietuvos fotografijoje atsirado ị šiai mokyklai būdingą humanistinę estetinę atvaizdo sampratą netelpančių kūrinių, turèjusių postfotografiškumo bruožų . Taigi tikslas buvo ne ankstesnių vietinių užuomazgų tąsa, o bandymas pasivyti jau keletą dešimtmečių gyvuojančias tarptautines tendencijas ir kritiškai komentuoti bei dekonstruoti vyraujančią vietinę tradiciją, tapusią prekiniu lietuviškos fotografijos ženklu. Dėl šios antagonistinès retorikos atsakas i pirmąsias postfotografijos apraiškas, ypač i parodą komentarai@3xpozicija.lt, kilo daugiausia fotografijos bendruomeneje ir Lietuvos fotomenininkų sajungoje. Pastarosios nariai Povilas Sigitas Krivickas, Aleksandras Macijauskas ir Romualdas Požerskis straipsniuose žurnale Nemunas ${ }^{5}$ apie naujaji reiškini pateikè skeptiškas nuomones ir įžvelgè jaunu̧jų postfotografijos šalininkų siekį „griauti tradiciją, kurios nežino“. Parodą uždarant surengtoje diskusijoje ${ }^{6}$ naują reiškini palaikè tuometinis LFS pirmininkas Antanas Sutkus ir sekretorius Stanislovas Žvirgždas - jie pripažino naujų alternatyvių raiškos priemonių vertingumą ir teigè, kad kiekviena nauja paroda ar reiškinys kelia iššūkị suvokimui. Savo ruožtu postfotografijos šalininkai bei juos palaikantys menotyrininkai ir kiti autoriai tame pačiame žurnale ir kituose leidiniuose ${ }^{7}$ siekè paaiškinti, kad postfotografijos esmè yra ne tradicinės figūratyviam atvaizdui pirmenybę teikiančios fotografijos sampratos griovimas, o kritinis fotografijos kaip reiškinio apmąstymas, jos sąsajų su kitomis medijomis tyrimas, fotografinès raiškos išplètimas už analoginio fotografinio atspaudo ribų ir įtraukimas i tarpdisciplininio šiuolaikinio meno kontekstą. Vis dèlto galima pastebėti, kad būtent pastarajame platesnių postfotografijos

4 Agnè Narušytė, „Postfotografijos pėdsakas Lietuvoje: pasižvalgymai po vietini kontekstą“, in: Postfotografija, p. 7-8; Valentinas Klimašauskas, „Fotografijos nuotykiai išplèstuose laukuose“, in: [re:] Fotografija, 2007, Nr. 1, p. 5; Vytautas Michelkevičius, „Smalsumas ir ieškojimai“, in: Postfotografija, p. 2-3.

5 Povilas Sigitas Krivickas, „Ar postfotografijos karalius neliks nuogas?“, in: Nemunas, 200612 14, Nr. 44 (132-573), p. 12-13; Aleksandras Macijauskas, „Ar jaunieji žino, ką griauna?“, in: ibid., 200701 04, Nr. 1 (135-576), p. 3; Romualdas Požerskis, „Visi post- yra konceptualizmas“, in: Nemunas, 200701 11, Nr. 2 (136-577), p. 11.

6 „Parodos uždarymas ir diskusija ,Komentarai fotografijai ir tarpdiscipliniškumui““, in: 3xposition.lt, [interaktyvus], 200611 08, [žiūrèta 2020-09-28], http://www.3xposition.lt/?p=121.

7 Tomas Pabedinskas, „Karalius nuogas!“, in: Nemunas, 200701 18, Nr. 3 (137-578), p. 4; Greta Grendaitè, „Pozicija: kritiškas konceptualumas“, in: ibid., 200701 25, Nr. 4 (138-579), p. 2, 14; Vytautas Michelkevičius, „Konceptualizmas išgelbėjo fotografiją: komentarų komentarai“, in: ibid., 200702 08, Nr. 6 (140-581), p. 14; Tautvydas Bajarkevičius, „Apie postfotografiją“, in: 7 meno dienos, [interaktyvus], 200611 10, Nr. 730, [žiūrèta 2020-09-28], http://www.7md.lt/archyvas.php?leid_ $\mathrm{id}=730 \&$ str_id $=6507$. 
reiškinio aptarimų nebuvo, o fotografinių priemonių ir formų naudojimas čia buvo apmąstomas retoriškai kiek kitaip.

Keičiantis LFS pirmininkams ir parodų kuratoriams, jos valdomose galerijose Vilniuje, Kaune ir Klaipėdoje daugejjo fotografijos raiškos ribas tiriančiu ir praplečiančiu grupinių ir asmeniniu parodų. Naujoviškos fotografinės formos tapo vis dažniau matomos ir šiuolaikinio meno institucijose, pavyzdžiui, Šiuolaikinio meno centre, galerijoje „Vartai“, Vilniaus dailès akademijos parodu salėse „Titanikas“ ir kitur. Tačiau kartu pastebima, kad postfotografija jau nebebuvo minima kaip aktuali tokios kūrybos analizès prieiga arba buvo aptariama retrospektyviai, kaip ankstesnė fotografijos lauko savivokos pakopa, nebūtinai atitinkanti šiuolaikinę vizualiosios kultūros būseną. Kai kurių fotografijos bendruomenès dalyvių, pavyzdžiui, fotografo ir kuratoriaus Pauliaus Petraičio, viešuose pasisakymuose apie reikalingas ideologines slinktis Lietuvos fotografijoje postfotografinis sajūdis apskritai neminètas. Vèlesniuose, XXI a. 2-ojo dešimtmečio antros pusės, parodiniuose šio ir kitų kuratorių projektuose ${ }^{8}$ išryškejjo dėmesys tokiems reiškiniams, kaip „mašininis matymas“, anoniminių vaizdų apytaka socialiniuose tinkluose, vaizdai kaip duomenu sankaupos, algoritminè fotografija ir t. t.

Apskritai galima teigti, kad fotografijos kilmès, raiškos ir ribu apmąstymas vyko daugiausia LFS ar jos narių organizuojamose parodose bei leidiniuose, o kitose institucijose fotografinès formos buvo pasitelkiamos platesnèms šiuolaikinės vizualinès kultūros problemoms nagrinèti. Ši aplinkybė leidžia pateikti preliminarią šio straipsnio prielaidą: postfotografijos diskursas kaip siekis įtraukti išplėstines fotografines priemones ị postmedialų šiuolaikinio meno lauką buvo svarbesnis tam tikrai fotografijos bendruomenès daliai nei šiuolaikinio meno bendruomenei, o kai šios priemonès i̦sitvirtino kaip viena iš daugelio šiuolaikinio meno raiškoje lygiavertiškai naudojamų medijų, poreikis ittvirtinti kitokias nei meninė fotografija fotografinio mąstymo formas natūraliai nunyko. Ṣ̌ nunykimą galima sieti ir su tuo, kad panašiu metu, apie 2010 m., Lietuvoje nuslopo ir postfotografijai artimas medijų meno diskursas ${ }^{9}$,

8 Nubrozdinti vaizdai (ŠMC, 2015, kuratorè Inesa Brašiškè), Nauji fotografijos įrankiai: nuo Google iki algoritmo (Vilniaus fotografijos galerija, 2018, kuratorius Paulius Petraitis).

9 Agnè Narušytė, Jurij Dobriakov, „Kas nutiko lietuviškam medijų menui?“, in: 7 meno dienos, [interaktyvus], 201511 20, Nr. 41 (1147), [žiūrèta 2020-09-28], http://www.7md.lt/ tarp_disciplinu/2015-11-20/Kas-nutiko-lietuviskam-mediju-menui; Lina Michelkevičè, Vytautas Michelkevičius, „Unwritten Histories of Extinct Media Art in Lithuania: From the 2000s of Great Promise to the Multidirectional 2010s“, in: Acoustic Space, t. 15, Riga: RIXC Center for New Media Culture and Liepaja: Art Research Lab (MPLab) of Liepaja University, 2016, p. 70-83. 
užleidęs vietą kitiems, konkrečioms raiškos priemonėms mažiau dėmesio skiriantiems meno judejjimams, tarkim, postinternetiniam menui, sutapusiam su domėjimusi įvairiomis automatinėmis „nežmogiškomis akimis“. Tačiau šiai prielaidai patvirtinti pirmiausia būtina apžvelgti, kaip iki $2010 \mathrm{~m}$. skyrèsi ịvairių fotografinių formų apmąstymas postfotografijos ir šiuolaikinio meno kontekstuose, o vėliau išnagrinèti, kaip keitėsi postfotografijos diskursas po 2010 m., ir apibendrinti jo poveikị tolesnei fotografinės minties raidai Lietuvoje.

\section{Sąvokų niuansai: meninè fotografija, fotografija šiuolaikiniame mene, postfotografija, fotografija išplèstiniame lauke, metafotografija}

Kaip jau minèta, ì Lietuvos meno gyvenimą postfotografijos sąvoka atejjo iš tarptautinio meno ir menotyros konteksto. Tiesa, pastarajame ji pradèta vartoti ne XXI a. pradžioje, o dešimtmečiu anksčiau, taigi jau turèjo vartosenos istoriją, nors jos reikšmė ir nebuvo nusistovėjusi. Galima teigti, kad pirmieji besiplečiančią techninių atvaizdų ir jų funkcijų ịvairovę apmąstyti siekę teoretikai (Davidas Tomas, Geoffrey Batchenas, Williamas J. Mitchellas $^{10}$ ) kalbejjo ne tik ir ne tiek apie postfotografiją kaip apie tradicinę meninę fotografiją keičiančią kūrybinę praktiką, o platesne prasme - apie „postfotografinę erą“, kai dèl kompleksinių technologinių, socialinių ir kultūrinių priežasčių ėmè nebegalioti arba problemiškos tapo ankstesnès matymo, vaizdavimo, tiesos / patikimumo ir medijų autonomijos kategorijos. Tačiau pradedant J. Mitchellu postfotografijos apmąstymuose įsivyravo skaitmeninių technologijų sukeliamų milžiniško masto pokyčių sureikšminimas, tad postfotografija kaip „fotografija po fotografijos“ imta tapatinti pirmiausia su skaitmeninės fotografijos teikiamomis naujomis galimybèmis bei ligtoliniam žinojimui keliamais iššūkiais ${ }^{11}$. Vis dèlto XXI a. 1-ajame dešimtmetyje George’as Bakeris nuo „skaitmeninio amžiaus“ technologinio determinizmo prieigos perèjo prie išplèstinio fotografijos lauko nagrinėjimo bendruoju

10 David Tomas, „From the Photograph to Postphotographic Practice: Toward a Postoptical Ecology of the Eye“, in: SubStance, t. 17, Nr. 1 (55), 1988, p. 59-68; Geoffrey Batchen, „On Postphotography“, in: Afterimage, t. 20, Nr. 3, 1992, p. 17; William J. Mitchell, The Reconfigured Eye: Visual Truth in the Post-Photographic Era, Cambridge, Mass.: MIT Press, 1992.

11 Pvz., žr. parodos Photography after Photography (Aktionsforum Praterinsel, Miunchenas, 1995) katalogą: Photography After Photography: Memory and Representation in the Digital Age, eds. Stefan Iglhaut et al., Amsterdam: Overseas Publishers Association, 1996. 
postmodernaus intelektinio projekto požiūriu ${ }^{12}$. Todèl nenuostabu, kad ir šiuo laikotarpiu Lietuvoje pasirodžiusiuose teoriniuose svarstymuose postfotografija buvo apibrèžiama ne techniniu požiūriu, o pirmiausia santykiu su vietos meno instituciju sistema ir jos palaikomomis tradicijomis.

2006 m. žurnale Postfotografija skelbiamuose tekstuose aiškiausiai nubrèžiama skirtis tarp meninès fotografijos (Lietuvoje dažnai vadinamos fotomenu) ir fotografijos šiuolaikiniame mene. Vytauto Michelkevičiaus kalbinamas Liljevachs meno centro Stokholme kuratorius Niclas Östlindas teigia, kad tai yra dvi atskiros kultūros, ir net aiškiai lokalizuoja jų veikimo teritorijas: kai natūrali meninès fotografijos aplinka yra fotografijos festivaliai (pavyzdžiui, Arlio), labiau teorijai nei estetiniam ir vizualiniam turiniui pirmenybę teikiančios fotografinès formos pristatomos moderniojo meno muziejuose ir šiuolaikinio meno galerijose ${ }^{13}$. Pašnekovai sutinka, kad meninè fotografija apibrěžiama pirmiausia fotografijos medija, tačiau N. Östlindas pateikia nuosaikesnị ir platesnị požiūrị - esą tam tikrų autorių kūrybos priskyrimas meninei fotografijai ar šiuolaikiniam menui yra susijęs ne tik su jos forma ar idejiniu pagrindu, bet ir su ,tinklais, turiniu, galerijomis ir rinka“14, o kai kurie autoriai, pavyzdžiui, Hiroshi Sugimoto, apskritai kuria darbus, tenkinančius abiejų sričių poreikius. N. Östlindas taip pat teigia: nemažai šiuolaikinio meno galerijose ar muziejuose eksponuojamų darbų išoriškai gali turèti nemažai bendrumų su menine fotografija, nepaisant kitokios reprezentacijos formos, ir šiuolaikiniame mene taip pat auga fotografinių darbų estetinės kokybės poreikis. Galiausiai jis suabejoja šiuolaikinio meno sampratos tvarumu ir klausia, kaip keisis apibrèžimai, kai ši samprata taps tik istorine etikete ${ }^{15}$.

Kitas V. Michelkevičiaus pašnekovas, Norvegijos Preus fotografijos muziejaus direktorius Jonas Ekebergas pasiūlo dar daugiau fotografijos diskurso pokyčių galimybių. Jis prisipažista, kad Norvegijoje fotografijos ir šiuolaikinio meno bendruomenių santykis vis dar paremtas abipusiu sutrikimu, o jo vadovaujama institucija rengia tiek griežtai meno scenai, tiek griežtai fotografijos istorijai skirtas, tiek mišraus pobūdžio parodas, tačiau visos šios kryptys muziejui yra svarbios, nes įvairių pozicijų priešinimas ir

12 George Baker, „Photography's Expanded Field“, in: October, 2005, Nr. 114, p. 120-140.

13 „Ieškant „post“ fotografijoje ir svarstant, kas galètų būti po šiuolaikinio meno“, in:

Postfotografija, 2006, Nr. (13), sud. Vytautas Michelkevičius, p. 20.

14 Ibid.

15 Ibid., p. 23. 
derinimas svarbesnis už geriausios pozicijos radimą ${ }^{16}$. Kartu jis pažymi, kad „pati įdomiausia fotografija šiandien produkuojama šiuolaikinio meno kontekste, ir ị tai reikia atsižvelgti, net ir siekiant išsaugoti fotografijos sceną ar fotografijos galerijas“"17, o pats neabejotinai jaučiasi priklausantis šiuolaikinio meno scenai. J. Ekebergas atskleidžia, kad asmeniškai jam priimtinesnė ne postfotografijos, o išplèstinio fotografijos lauko samprata, neteigianti postmodernistinės „fotografijos pabaigos“ ar vienareikšmiškos būsenos „po fotografijos“. Anot jo, demokratiškesnis ir liberalesnis požiūris teigia fotografijos daugialypumą, daugelio fotografijos sampratų sugyvenimą; konservatyvi prieiga linkusi besąlygiškai teigti, kad tradicinės fotografijos formos (dokumentinė ir meninė fotografija) vis dar išlieka gyvos ir aktualios, o postfotografinè perspektyva remiasi kalbėjimu apie postkolonijinio pasaulio aktualijas: migraciją, galią, feminizmą. J. Ekebergas stengiasi suderinti pirmą ir paskutini požiūrius, tikèdamas atvaizdo pritaikomumu ir neatmesdamas postmodernios atvaizdo kritikos. Tad išplèstinio fotografijos lauko programai jis pasiūlo tris pagrindinius elementus: fotografijos istoriją, šiuolaikinị meną, vizualinę kultūrą.

A. Narušytė apžvelgdama lietuviškų postfotografinių praktikų istoriją teigia, kad XX a. 10-ajame dešimtmetyje Lietuvos šiuolaikinio meno kūrèjai beveik nedirbo su fotografija tikslingai, išskyrus kelias išimtis arba nerefleksyvų fotografinių atvaizdų panaudojimą, todèl postfotografinio požiūrio ì juos ar skirtingų meno formų (pvz., tapybos ir fotografijos) susikirtimo pavyzdžių aptinkama daugiausia po 2000 metų ${ }^{18}$. Autorės manymu, nepaisant vis dar stiprių meninès fotografijos pozicijų Lietuvoje, čia kyla susidomėjimas ir postfotografinèmis formomis, o jauniausiajai fotografu kartai šiuolaikinio meno kontekstas yra natūralesnè terpè nei fotografijos meno laukas. Postfotografija A. Narušytės apibrèžiama bendriausia prasme kaip fotografija, „žvelgianti ị save iš šalies, dažniausiai - šiuolaikinio meno akimis"19. Tautvydas Bajarkevičius parodos komentarai@3xpozicija.lt apžvalgoje taip pat rašo, kad ,aiškesnius kontūrus ir prasminị krūvị postfotografijos sąvoka ịgauna būtent susidūrusi su šiuolaikinio meno lauku ir medijų bei vizualine kultūra“20, nors ir pažymi, kad Lietuvos šiuolaikiniame ibid., p. 49.

16 „Išplèstinis fotografijos laukas ir fotografijos institucijos šiuolaikinio meno scenoje“, in:

17 Ibid., p. 46.

18 Agnė Narušytè, „Postfotografijos pėdsakas Lietuvoje“, p. 8-10.

19 Ibid., p. 12.

20 Tautvydas Bajarkevičius, „Apie postfotografiją“. 
mene ši sąvoka yra gana nauja. Skirtis tarp tradicinès (meninės) fotografijos ir fotografijos šiuolaikiniame mene, pasak autoriaus, yra tai, kad pastarajam fotografijos veikimo režimui fotografinė forma nebūtina, o interpretacijos priemonėmis gali tapti kitos medijos.

Bene tiesmukiausias teiginys apie fotomeno ir fotografijos šiuolaikinio meno lauke santyki aptinkamas V. Michelkevičiaus straipsnyje Klaipédos dienraščio kultūros ir meno priede Durys, skirtame 2006 m. Erozijos bienalei. Autoriaus manymu,

fotomeno $<\ldots>$ niekas neberodo šiuolaikinio meno galerijose ir centruose, apie ji nustojo rašyti kritikai. < ...> Fotomenininkai negali susitaikyti su mintimi, kad kinta fotografijos forma ir turinys. O šie faktai labai džiugina antrają stovyklos pusę, kuri su pakylëjimu kalba apie fotografijos santuoką su kitomis medijomis bei šiuolaikiniu menu. ${ }^{21}$

Jis leidžia suprasti, kad būtent fotografijos ịtraukimo ị bendrą šiuolaikinio meno raiška šalininkai, užuot skelbę fotografijos pabaigą ar mirtị, sveikina jos atgimimą kitose medijose bei užsimezgančias sąsajas su tokiomis formomis, kaip videomenas, kompiuterinè grafika ar internetas. Kiek nuosaikiau panašias mintis išreiškė ir bienalès kuratorius G. Skudžinskas - tiesa, jo komentare juntamas kiek didesnis susitelkimas konkrečiai i fotografijos sampratą ir istoriją, nors ir išplečiant jų aprèptị:

Projektas palietė kone visas fotografijos ir gretutinių vizualinių menų raiškos kryptis, o tai ir yra vienas iš pagrindinių projekto sumanymų - apžvelgti ir pristatyti fotografijos žanro lankstumą ir ịvairialypiškumą. <...> Projektas sumanytas kaip žanro ribų tyrimas, bet kad procesas netaptų destruktyvus ir tik savitikslis ribų perženginėjimas, jis visuomet aiškiai apibrèžè savo ryši su chrestomatinėmis fotografijos tradicijomis. < ...> Gal ir nèra paprasta Erozija i isprausti tik i fotografijos rèmus, greičiau tai „žmonių su kameromis“ kūrybą pristatantis renginys, kurị labiau galètume apibrèžti kaip atvaizdo ar vizualiosios kultūros projektą. Autoriai nutolsta nuo pirminės fotografijos funkcijos kurti tikrovès ikonas, ir kūriniai tampa mentaliniais žemėlapiais šiuolaikinio vizualinio meno platumose. ${ }^{22}$

21 Vytautas Michelkevičius, „Komunikacijos malonumai, arba Ką gali mano mobilusis telefonas“, in: Durys, 200611 29, Nr. 138, p. 10.

22 Gytis Skudžinskas, „Erozija‘: 325 dienos su fotografija“, in: ibid., p. 7. 
Grịžtant prie nedviprasmiškai postfotografine pavadintos parodos komentarai@3xpozicija.lt reikšminga aplinkybė atrodo tai, kad kuratorius $\mathrm{V}$. Michelkevičius šią parodą susieja ne tik su šiuolaikinio meno, bet ir konkrečiau - su medijų meno lauku [NB: esamo straipsnio autorius laikosi nuostatos, kad ideologinės šiuolaikinio meno ir medijų meno sistemos nèra tapačios, o neretai ir prieštarauja viena kitai23 ${ }^{23}$. Jo teigimu, toks patikslinimas įmanomas:

darant prielaidą, kad čia dalyvauja skirtingos medijos, kurių viena neiškeliama aukščiau už kitą, bei apibūdinant medijų meną kaip meno kūrinius, siekiančius kritiškai permąstyti medijas, jų veikimo mechanizmus bei meninius ir komunikacinius kontekstus. $^{24}$

Tačiau 2007 m. žurnale Fotografija pasirodžiusiame V. Klimašausko ir M. Matulytès pokalbyje pastaroji suabejoja šiuo priskyrimu, esą kontekstinis šios parodos laukas yra fotografija, o ne mediju menas platesne prasme $^{25}$. Be to, parodoje dalyvaujantys autoriai komentuodami fotografija ne tiek išreiškè natūralią postfotografinę būseną, kiek ieškojo tokią būseną ịrodyti turinčių kuo originalesnių formų, o jų pranešimai didžiaja dalimi kartojo ŠMC parodų jau gerai įtvirtintus svarstymus apie įvairias posttendencijas. Autorè netgi abejoja giluminio vertybinio konflikto tarp LFS ir jaunujų postfotografijos šalininkų tikrumu, pažymėdama, kad nemažos dalieskomentarai@3xpozicija.lt ir kitų panašaus pobūdžio parodų dalyvių (dažnai tos pačios VDA Fotografijos ir medijos meno katedros studentų ar absolventų bendruomenès narių) kūryba jau buvo skelbta ir LFS metraštyje, o pastarojo atsinaujinimas (2005-2006) ir didèjantis atvirumas konceptualioms idėjoms veikiau liudija ideologinị skilimą ir bręstančias pažangias permainas sajungoje nei kovą su jos „išorèje“ vykstančiais poslinkiais ${ }^{26}$.

23 Plačiau žr. Claire Bishop, „Digital Divide: Contemporary Art and New Media“, in: Artforum, 2012 rugsejjis, t. 51, Nr. 1; Lauren Cornell, Brian Droitcour, „Technical Difficulties“, in: Artforum, 2013 sausis, t. 51, Nr. 5.

24 Vytautas Michelkevičius, Gidas po postfotografijos teritorija internete ir galerijoje, Vilnius: VšI Mene, 2006.

25 Valentinas Klimašauskas, „Fotografijos nuotykiai išplèstuose laukuose“, p. 5.

26 Ibid., p. 7. 
Idomu, kad V. Klimašauskas, kurị dèl jo veiklos galima priskirti šiuolaikinio meno bendruomenei (tuo metu jis buvo vienas iš ŠMC parodų kuratorių), savo replikoje teigia:

naujos postfotografinès vertybės, nors ir ne taip drąsiai, buvo pratęstos ir kitoje fotografijos parodoje Aš, tu ir kiti kadrai Šiuolaikinio meno centre (kuratore Renata Dubinskaitė) ir tapo aišku, kad yra susijusios su bendromis jaunosios kartos vertybèmis. $^{27}$

Čia svarbu ne tik tai, kad minima jaunujų menininkų paroda menotyrininkès Monikos Krikštopaitytės buvo apibūdinta kaip „kuklaus užmojo, daugiau pačią madą domètis naujienomis konstatuojanti“, palyginti su 3xpozicijos projektu, kuris ,ivedè ị apyvartą „postfotografijos“ terminą, ịkvèpè virtualų kūrinių gyvenimą bei leido stebèti, kaip kūriniai migruoja iš vienos medijos ị kitą ${ }^{\text {"28. }}$. Reikšmingiau atrodo faktas, jog tai yra vienas iš vos kelių atvejų, kai postfotografijos terminas yra vartojamas Lietuvos šiuolaikinio meno lauko dalyvio (kaip laukas čia suprantamas šiuolaikinị meną programiškai eksponuojančių ir legitimuojančių parodinių institucijų bei jų darbuotojų ir partnerių tinklas).

V. Klimašausko tekstai įtraukti i tris sąlyginai „postfotografinius“ žurnalo Fotografija 13-15 numerius (2006 ir 2007), o sudvigubintą Nr. 16-17 (2008 m. sausis-gruodis) jis pats sudarè su kita ŠMC kuratore - Julija Fomina. Tačiau šiuose tekstuose (išskyrus minètą polemiką su M. Matulyte, pateiktą kaip struktūrinę V. Klimašausko autorinio teksto dalį) autorius nenagrinèja fotografijos ir postfotografinio jos apmąstymo bei medialumo problematikos - veikiau kalba laisvojo meninio rašymo režimu apie įvairių rūšių vaizdų funkcijas ir anomalijas šiuolaikinëje vizualinèje populiariojoje kultūroje plačiausia prasme. Daugiausia panašiai tematikai skirtas ir minètas V. Klimašausko ir J. Fominos sudarytas Fotografijos numeris, kurio problemini pjūvị apibrèžia labai plačiai interpretuojamas reikšminis žodis „manipuliacijos“.

Šiuo požiūriu dar reikšmingesnis yra žurnalo ŠMC Interviu 11/12 numeryje (2008), skirtame apžvalginei parodai Lietuvos daile ‘08. 
Fotografija, skelbiamas J. Fominos ir V. Klimašausko pokalbis apie jų kuruotą šios parodos dali Kai vaizdas tampa pokalbiu. Jame J. Fomina užsimena, kad svarbiausias parodos rengimo ir menininkų idejų taškas buvo mintis, „kad fotografija yra medija konceptualiems sprendimams igyvendinti“, o V. Klimašauskas patikslina, jog pirmiausia jie, kaip kuratoriai, turèjo „pagalvoti, kiek prasminga apie šiuolaikinị meną mąstyti vienos medijos (šiuo atveju, fotografijos) aspektu“, taip pat iškilęs svarbus klausimas - „kas daro fotografiją šiuolaikiniu menu arba, mąstant postfotografiškai, koks šiuolaikinio meno procesas gali būti ịvardintas kaip fotografiškas “29. J. Fominos nuomone, kaip fotografiški gali būti apibūdinti šiuolaikinio meno procesai, paremti sąmoningu pranešimo konstravimu, o ne i saviraišką orientuoti užbaigti kūriniai, būdingi modernizmo paradigmai. Abu pašnekovai mini vaizdų infliaciją (milžinišką prasmės požiūriu mažaverčių viešojoje erdvėje plintančių ir dauginamų fotografinių atvaizdų skaičių) kaip vieną iš pagrindinių veiksnių, dèl kurių šiuolaikiniai menininkai vengia naudoti fotografijos mediją.

Nors V. Klimašausko pasisakyme aiški nuoroda i postfotografinị mąstymą, o parodoje Kai vaizdas tampa pokalbiu dalyvauja dalis parodoje komentarai@3xpozicija.lt dalyvavusių menininkų (Akvilè Anglickaitè, Arturas Bumšteinas, Tomas Čiučelis, Gintaras Didžiapetris, Robertas Narkus), galima pastebėti akivaizdžius retorinius skirtumus palyginti $\mathrm{su}$ fotografijos lauke išplètotu postfotografijos diskursu. Priešingai nei 3xpozicija.lt bendruomenė ar Erozijos rengèjai, aptariamame pokalbyje kuratoriai praktiškai nemini fotografijos istorijos, institucinès sistemos arba medialių savybių. Jiems svarbesni bendros populiariosios vaizdų kultūros procesai, o mąstymas remiantis viena medija (net ir kritiškai ja nagrinėjant) medijų lygiateisiškumu paremto šiuolaikinio meno kontekste atrodo įtartinas. Atsižvelgiant ị tai, kad V. Klimašauskas iš arti stebèjo fotografų bendruomenèje ir šalia jos vykstančias diskusijas apie postfotografiją, galima daryti prielaidą, jog pastarosios tapo vienu iš motyvu rengiant parodą ŠMC, tačiau kartu jaučiamas siekis atsiriboti nuo meninès fotografijos tradicijos ir rasti prieigą prie šiuolaikiniame mene naudojamų fotografinių priemonių i šią tradiciją nenurodant. Čia fotografija suvokiama

29 Julija Fomina, Valentinas Klimašauskas, „Kai vaizdas tampa pokalbiu“, in: Interviu, 2008, Nr. $11 / 12$, p. 38 . 
kaip neatsiejamas šiuolaikinės vizualinės kultūros dėmuo, vis dèlto neturintis jokio privilegijuoto statuso palyginti su kitomis medijomis.

Apžvelgus įvairių interesų grupių išreiškiamą požiūrị i fotografijos ir šiuolaikinio meno santykį, būtina išsiaiškinti, kaip postfotografijos sąvoka apibrèžiama toje terpèje, kurioje ji pradèta vartoti Lietuvoje - t. y. postfotografijos bendruomenejje, atsiradusioje polemizuojant su Lietuvos fotografijos mokyklos tradicijos šalininkais. Beveik visi aptinkami apibrèžimai išskiria meninėje fotografijoje iki tol tarsi nepaisytą fotografijos medialumą, tačiau dar kartą reikia pasakyti: fotografijos post- būsena čia nesiejama su technologiniais veiksniais, t. y. postfotografija netapatinama su skaitmenine fotografija, kuri gali būti pritaikyta ir tradicinei meninès fotografijos sampratai. V. Michelkevičiaus teigimu:

postfotografija prasideda tada, kai bandome apsispręsti, koki požiūrio kampą ị fotografiją pasirinksime. < ..> Postfotografija - tai reflektavimas pačios fotografijos tradicijos, tai vieno puslapio užvertimas ir bandymas suvokti tai, kad esame jau „post būsenoje“, lietuviškiau tariant - „būsenoje po kažko“. ${ }^{30}$

Vardydamas parodos komentarai@3xpozicija.lt rengimo tikslus jis išskleidžia postfotografijos apibrèžimą ir ịveda papildomą metafotografijos (apmąstančios save) sąvoką - tiesa, vėliau ji nevartojama.

Galvoje sukosi du tikslai: suburti jaunus menininkus, kuriems aktualios fotografinès problemos šiuolaikiniame mene, bei reflektuoti naujas fotografinio atvaizdo (ne)kūrimo tendencijas. Pirmajị tikslą ịvardinčiau žodžiu metafotografija, antraji postfotografija. $<\ldots>$ parodos negalima pavadinti tiesiog fotografijos paroda, nes tai - paroda apie fotografiją. ${ }^{31}$

Toliau autorius sutraukia šiuos tikslus iki vieno: įvertinti fotografijos kaip medijos vaidmenị ir būseną Lietuvos šiuolaikinio meno kontekste, o ì postfotografijos problemų ratą ittraukiami tokie reiškiniai kaip fotografijų naudojimas, reprezentacijos problema mene, fotografijos komunikatyvumas, vizualumo pagrindo bei jo suvokimo paieškos, technologinès 
fotografijos savybės ir santykis su kitomis medijomis bei jos kaip medijos veikimas.

Čia pat V. Michelkevičius pažymi, kad postfotografijos samprata (tarptautiniu mastu) per kelis savo gyvavimo dešimtmečius jau spèjo patirti ir reikšmingų pokyčių:

technologiškai - išeksploatavus visas skaitmenines galimybes paskutiniajame $\mathrm{XX}$ a. dešimtmetyje ir vėl grižus prie skaidraus technologinio betarpiškumo, konceptualiai - sunykus fotomeno galiai ir fotografijai ištirpus medijų meno ir šiuolaikinio meno sąvokose..$^{32}$

Šią nuomonę papildo N. Östlindo teiginys, kad postfotografijos sąvokos turinys kinta, ir tai priklauso nuo istorinių aplinkybių:

anuomet buvo svarbu deklaruoti, kad mes pasiekėme tašką, savitą fotografijos tradicijai/istorijai. Dabar atsiranda kiti dalykai; šiandien mes turime pradèti kalbėti apie postfotografiją, tiesiog norėdami išryškinti, kas yra nauja ir kas vyksta. < ..> Postfotografija veikiausiai yra fotografijos istorijos dalis, bet ta fotografijos istorija išsiplètė ir tapo vizualinès kultūros istorijos ir kultūros studijų dalimi, taigi dabar ji suvokiama platesne prasme. ${ }^{33}$

Jo nuomone, nors XX a. 9-ojo dešimtmečio pabaigoje postfotografija iškilo kaip priešprieša dokumentinès ir meninės fotografijos tradicijai, pirmajame naujojo tūkstantmečio dešimtmetyje ji daug labiau suartèjo su tradicine fotografijos samprata, o pagrindinè postfotografinių praktikų savybè - savivoka medijos ir reprezentacijos sąlygų atžvilgiu - būdinga net ir šiuolaikinei dokumentinei fotografijai.

A. Narušytès nuomone, „postfotografijos suvokimas nėra paprastas - vos tik išsiaiškini, ką ji nori pasakyti, ji tuoj pat tai paneigia, bet paneigs ir tai, ką tarsi teigtų savo pirmuoju paneigimu“34. Greta Grendaitė apžvelgdama diskusiją, kilusią apie parodąkomentarai@3xpozicija.lt, teigia, kad postfotografijos terminas nelabai tikslus ar aktualus postmedialaus šiuolaikinio meno požiūriu ir todèl tikriausiai nebus ilgalaikis: 
Postfotografija simboliškai gali apibrèžti menininko savivokos pakitimus, tačiau terminas nėra pakankamai tikslus, kad pajėgtų nusakyti naują meninės fotografijos srovę. Jis greičiau atveria galimybes naujų krypčių paieškai, nei jas determinuoja. Šiuolaikinis fotografas nekuria fotografinio atvaizdo vien fotografijos menui palaikyti. Menininkas, naudodamasis fotografijos teikiamomis galimybėmis, parodo veikiau ne savo pomėgị šiai technikai, bet išreiškia save, ir dažniausiai tai daro ne per fotografijos meną autonomine jo prasme, o per šio meno simbiozę su kitomis medijomis. $^{35}$

Panašiai parodos recenzijoje svarsto ir T. Bajarkevičius - nors šis autorius pripažįsta postfotografijos idejų naujumą ir reikalingumą, jis pažymi, kad sąvokos vartosena kelia daug klausimų:

Pats terminas „postfotografija“ yra ne uždaras apibrèžimas, o labiau išplèstinė sąvoka, žyminti galimas jo interpretacijų galimybes. Panašu, kad jis yra labiau taikomojo, nei aprašomojo pobūdžio. Tai diskursyvi nuoroda ị kontekstą, santykị ar tam tikrą meninị lauką. Bendruomenès tinklalapyje www.3xpozicija.lt taip pat galima rasti daugiau „mitų apie postfotografiją“ nei jos apibrèžimų. Šiuo konkrečiu atveju postfotografijos reikšmės tampa paieškų, diskusijų ir eksperimentų objektu. Netgi tarptautiniame kontekste nenusistovejusi termino vartosena lemia gana savarankišką jo supratimą ir lokalias interpretacijas. ${ }^{36}$

Bene konkrečiausiai postfotografijos reiškinio kontūrus nubrèžia J. Ekebergas, pateikdamas kertinius ji formuojančius diskursus. Šie yra: 1) atvaizdo skaitmenizacija; 2) su pastaruoju susijusi dokumentinio atvaizdo ir tikrovès krizè; 3) meninès fotografijos iškilimas ir fotografijos bei meno institucijų mišimas; 4) lingvistika, semiotika, atvaizdo kaip teksto samprata bei susijusios radikalaus mąstymo srovès - marksizmas ir postmarksizmas, postkolonializmas, postmodernizmas ${ }^{37}$. Vis dèlto galima įžvelgti ir šio apibrèžimo problemiškumą - pavyzdžiui, bent jau Lietuvoje meninė fotografija su savo kanonu buvo vienas iš pagrindinių postfotografinės kritinės dekonstrukcijos objektų, o fotografijos ir (šiuolaikinio) meno teritorijos tebebuvo

35 Greta Grendaitè, „Pozicija: kritiškas konceptualumas“, in: Nemunas, 200701 25, Nr. 4 (138-579), p. 14.

36 Tautvydas Bajarkevičius, op. cit.

37 „Išplèstinis fotografijos laukas“, p. 46. 
gana aiškiai atskirtos ir XXI a. 1-ajame, iš dalies tokios liko ir 2-ajame dešimtmetyje.

Visi čia įvardyti teoriniai svarstymai Lietuvoje ịvyko dvejų metu laikotarpyje, 2006-2008 m. Vèliau tokio masto polemika konkrečiai apie postfotografijos teikiamas galimybes nebeišsivystè, tačiau norint įvertinti išliekamają aptartų postfotografinių idèjų ir iniciatyvų vertę bei fotografijos ịtraukimo ị šiuolaikinio meno praktiką lygị būtina apžvelgti svarbius vẻlesnio dešimtmečio ịvykius ir heterogeniškas fotografijos aplinkas po 2010-ujų.

\section{Po 2010-ujų: naujos kryptys ir išsklidę kontekstai}

XXI a. 2-ojo dešimtmečio pradžioje postfotografija minima A. Narušytės 2011 m. pasirodžiusios knygos Lietuvos fotografija: 1990-2010 38 skyriuje „Postfotografija ir fotosofija“. Tiesa, čia daugiau dèmesio skirta Lietuvos postfotografijos pirmtakams, kurie patys šios sąvokos savo kūrybai apibūdinti nevartojo, pavyzdžiui, Gintautui Trimakui ir Alvydui Lukiui. Tačiau ir jaunųjų postfotografijos šalininkų sajūdis, regis, apleido postfotografijos diskursą - tais pačiais $2011 \mathrm{~m}$. dalis su 3xpozicija.lt bendruomene susijusių žmonių (Vytautas Michelkevičius, Tadas Šarūnas, Akvilè Anglickaitè, Robertas Narkus), dabar jau vienijami meninių iniciatyvų ir leidybinių projektų organizacijos Vš I Mene, surengė naują tarptautinị parodinị ir leidybini projektą Vietos karta: atvaizdas, atmintis ir fikcija Baltijos šaly$s e^{39}$. Nors šis projektas iš dalies taip pat nagrinèjo išplèstinius fotografijos keliamus klausimus (fiktyvumą, atminties reprezentacijos ir manipuliacijos strategijas, vaizdo ịvietinimą), vis dèlto didžiaja dalimi formaliai jis susitelkè ì gana tradicinius fotografinius atvaizdus (nepaisant meninei fotografijai netradicinio turinio), o parodojekomentarai@sxpozicija.lt deklaruotos medijų hibridizacijos praktiškai nebebuvo. Galima teigti, kad Vietos karta buvo artimesnè šiuolaikinio meno nuostatai, nesureikšminančiai konkrečiai medijai būdingų problemų ir pirmenybę teikiančiai kūrinio koncepcijai. Kai kuriems iš dalyvavusių menininkų (pvz., Ugniui Gelgudai) tai buvo ir bene paskutinis jų kūrybinėje karjeroje konkrečiai su fotografija susijęs projektas - vèliau jie visiškai perèjo prie daugybę išraiškos priemonių naudojančio šiuolaikinio meno.

38 „Postfotografija“, in: Agnè Narušytè, Lietuvos fotografija: 1990-2010, Vilnius: Baltos lankos, p. 275-289.

39 Vietos karta: atvaizdas, atmintis ir fikcija Baltijos šalyse, sud. Vytautas Michelkevičius, Vilnius: VšI Mene, 2011. 
Svarbu paminèti ir tai, kad metais anksčiau, 2010-aisiais, aktyvią veiklą nutraukẻ nuo $2005 \mathrm{~m}$. veikęs internetinis medijų kultūros žurnalas balsas.cc, kurio autoriai ir auditorija beveik sutapo su 3xpozicija.lt bendruomenès. Šio žurnalo skleidžiama naujujų medijų kultūra ir naujuјju medijų menas iš esmès ir buvo natūrali postfotografijos judejjimo Lietuvoje terpè, nes ir žurnalas buvo ịkurtas medijų menininkų Nomedos ir Gedimino Urbonų bei V. Michelkevičiaus kaip atsakas ị tai, kad medijų menas buvo menkai atstovaujamas Lietuvos šiuolaikinio meno institucijų. Tad galima palyginti medijų meno ir postfotografijos padètị vietos meno ekosistemoje: abu diskursai buvo perimti iš tarptautinès vartosenos, buvo savotiškai marginalūs Lietuvoje vyraujančių meno kalbų (postkonceptualaus šiuolaikinio meno, meninès fotografijos) atžvilgiu ir neturëjo fizinių savo institucijų, nemaža dalis aktyvių veikẻjų lygiagrečiai plètojo abu diskursus, galiausiai abu nuslopo sumenkus susidomėjimui medialumu ar reikšmingai bendruomenès daliai perejjus į dominuojantị šiuolaikinio meno kontekstą ir pakeitus savo meninès ar kuratorinès praktikos pobūdį ${ }^{40}$.

$2014 \mathrm{~m}$. postfotografija buvo vèl prisiminta, tačiau jau kitomis aplinkybėmis. Ši kartą polemiką paskatino LFS ideologinės inercijos kritika iš kitos stovyklos - šiek tiek jaunesnių už vadinamają ,vietos kartą“ fotografų. Pastarujų nuostatą išreiškè menininkas ir kuratorius Paulius Petraitis (dar žinomas kūrybiniu slapyvardžiu Paul Paper). 2012 m. žurnale Kultūros barai jis paskelbė straipsni „XXI a. reprezentuoja XX a. viziją? Lietuvos fotografijos metraščiai"“11, kuriame kritiškai atsiliepè apie LFS praktikuojamą metraščiu Lietuvos fotografija: vakar ir šiandien sudarymo politiką: ji esą sistemiškai diskriminuoja jaunų, dažnai užsienyje gyvenančių lietuvių fotografu kuriamą savitos konceptualios fotografijos krypti. Tačiau didesni sąmyšį sukèlè ne šis tekstas, o $2013 \mathrm{~m}$. pabaigoje išleista P. Petraičio ir tuometinės „Rupert“ meno ir edukacijos centro meno direktorès Justės Jonutytès sudaryta knyga Tarsi nebūtu rytojaus. Jaunosios kartos Lietuvos fotografija ${ }^{42}$, pristačiusi Lietuvoje menkai matomą minètos jaunų fotografų bendruomenės kūrybą. Knygos išleidimo proga pasirodžiusiame Sandros Drūlytès pokalbyje su sudarytojais P. Petraitis teigè:

40 Agnė Narušytė, Jurij Dobriakov, „Kas nutiko lietuviškam medijų menui?“.

41 Paulius Petraitis, „XXI a. reprezentuoja XX a. viziją? Lietuvos fotografijos metraščiai“, in: Kultūros barai, 2012, Nr. 1, p. 45-48.

42 Tarsi nebütu rytojaus. Jaunosios kartos Lietuvos fotografija, sudare Justė Jonutyte ir Paulius Petraitis, Vilnius: Rupert, 2013. 
lietuvių fotografija pasauliniame kontekste buvo atsilikusi, ypač nuo konceptualiosios fotografijos, kuri čia taip ir neivvyko tada, kai kitur jau klestejo. Leidinyje pristatyti autoriai - bene pirmą kartą šalies fotomeno istorijoje - žengia koja kojon su progresyviais kolegomis, keldami klausimus, kurie aktualūs pasauliniame fotografijos meno kontekste. ${ }^{43}$

Šios naujos fotografų kartos išreikštos pozicijos neistoriškumas (visai nesenų Lietuvos šiuolaikinio meno ir fotografijos reiškinių, tarp jų ir postfotografijos judėjimo ar Erozijos bienalių, sąmoningas ar nesąmoningas nutylèjimas ${ }^{44}$ ) bei jų kūrybos susitelkimas ị estetiką, o ne ị fotografijos medijai svarbių problemų apmąstymą (nepaisant P. Petraičio pabrèžto siekio „permąstyti pasikeitusią medijos situaciją“ bei pristatyti „fotografiją, kuri yra apie pačią mediją - apie fotografiją kaip kultūrini vyksmą ir su juo susijusias konotacijas“), lèmè svarstymus kultūros spaudoje ${ }^{45} .2014 \mathrm{~m}$. balandžio 3-23 d. jie išsiplètė ir ị viešają erdvę, kai Nacionalinès dailès galerijos auditorijoje P. Petraitis ir tuometinė NDG kuratorė Dovilė Tumpytė surengẻ šiuolaikinei fotografijai skirtą paskaitų ir pokalbių ciklą Kas néra fotografija? ${ }^{46}$. Šio straipsnio autorius dalyvavo pirmame ciklo pokalbyje $B e$ siplečianti fotografija: XXI amžiaus klausimai, taip pat skaitė paskaitą Lietuvos fotografija po postfotografijos. Pastarojoje siekta apmąstyti 2004$2014 \mathrm{~m}$. vykusius Lietuvos fotografijos raidos procesus, atskleisti šiuolaikinès lietuviškos fotografijos sampratų ịvairovę ir tarpusavio santykius, aptarti postfotografijos bei fotografijos šiuolaikinio meno lauke sąvokas įtvirtinusios menininkų ir tyrèjų kartos kūrybą po $2010 \mathrm{~m}$.

43 „Tarsi nebūtų rytojaus - interneto kartos žinutė tarp dviejų viršelių“, in: Kita fotografija, [interaktyvus], 201401 24, [žiūrèta 2020-09-28], http://web.archive.org/web/20160412122309/http:// www.kitafotografija.lt/tarsi-nebutu-rytojaus-interneto-kartos-zinute-tarp-dvieju-virseliu-interviu-sujuste-jonutyte-ir-pauliumi-petraiciu-5293.

44 Tai galima pagrịsti P. Petraičio teiginiu, kad knyga yra ,iki šiol Lietuvoje neitvykusio ir itin reikalingo dialogo - pokalbio apie šiuolaikinę fotografiją ir jos vietą šiandieninèje kultūroje - paieška ir formavimas".

45 Jurij Dobriakov, „(Vis dèlto,) kas yra Lietuvos šiuolaikinė fotografija?“, in: artnews.lt, [interaktyvus], 201402 01, [žiūrèta 2020-09-28], http://artnews.lt/vis-delto-kas-yra-lietuvos-siuolaikinefotografija-22553; Agnè Narušytè, „Tarsi nebūtų fotografijos“, in: 7 meno dienos, [interaktyvus], 201404 01, Nr. 14 (1075), [žiūrèta 2020-09-28], http://www.7md.lt/fotografija/2014-04-11/Tarsi-nebutufotografijos; Eadem, „Testas fotografijos laukui“, in: '7 meno dienos, [interaktyvus], 201404 18, Nr. 15 (1076), [žiūrèta 2020-09-28], http://www.7md.lt/daile/2014-04-18/Testas-fotografijos-laukui.

46 „Paskaitų ir pokalbių ciklas Kas nèra fotografija Nacionalinèje dailès galerijoje“, in: Kita fotografija, [interaktyvus], 201403 31, [žiūrèta 2020-09-28], http://web.archive.org/ web/20150602235334/http:/www.kitafotografija.lt/paskaitu-ir-pokalbiu-ciklas-kas-nera-fotografijanacionalineje-dailes-galerijoje-5702. 
Tačiau minètas renginių ciklas kaip visuma parodè, jog beveik dešimtmečiu anksčiau pasiūlyta postfotografijos sąvoka nepajėgi aprėpti po jos ìvykusių fotografinio diskurso pokyčių, o fotografinio atvaizdo kaip integralios šiuolaikinio meno dalies suvokimas gali skirtis iš esmès ir priklauso nuo konkrečios kartos, bendruomenès, institucinių saitų ar net asmeninės patirties. Taip pat paaiškėjo, jog naujajame dešimtmetyje daug svarbesni ,interneto kartai“ iprasti reiškiniai: ne fotografijos esmès ir ribu tyrimas, o nesustabdomo dekontekstualizuotų anoniminių vaizdų srauto liudijimas, online mąstymas vaizdais, perëjimas prie mašininio matymo, fotografinių vaizdų kaip duomenų sankaupų ir algoritminės fotografijos. Šie posthumanistinei prieigai artimi reiškiniai vèliau plačiai atsiskleidè parodose Nubrozdinti vaizdai (2015, ŠMC, kuratorè Inesa Brašiškè), P. Petraičio kuruotoje grupinèje parodoje Nauji fotografijos irankiai: nuo Google iki algoritmo (2018, VDA Nidos meno kolonija ir LFS Vilniaus fotografijos galerija) bei jo asmeninejje parodoje Vyras su tamsiais plaukais ir saulèlydžio fone (2019, „Lokomotif“ erdvè).

Vis dèlto postfotografijai būdingi fotografijos mediją komentuojantys ir dekonstruojantys kūrybiniai principai po $2010 \mathrm{~m}$. neišnyko visai. 2014 m. šio straipsnio autorius kuravo grupinę parodą Fotografijos grüdas (Kauno fotografijos galerija $)^{47}$, joje siekta aptikti fotografinio mąstymo apraiškų ar pėdsakų kitas medijas naudojančioje kūryboje. Asmeninėje kūrybinėje kai kurių menininkų praktikoje, taip pat leidybinėje ir kuratorinėje jų veikloje postfotografinius principus galima atsekti iki pat $2020 \mathrm{~m}$. Vienas ryškiausių jiems ištikimų kūrẻjų yra G. Skudžinskas (nors postfotografijos sąvokos savo kūrybai apibrèžti pats nevartoja), pastarajij dešimtmeti aktyviai reiškęsis tiek kaip LFS kuratorius bei metraščiu sudarytojas, tiek kaip individualus menininkas ir nepriklausomas meninių knygų leidejjas. Jo sudarytuose LFS metraščiuose 2014 m. atsirado skyrius Šalia fotografijos, skirtas ị tradicinę fotografijos sampratą netelpančiai menininkų kūrybai, o visas metraščio 50-aji jubiliejų žymintis $2017 \mathrm{~m}$. numeris, skirtas temai $M e$ dija ir visuomene $\dot{e}^{48}$, pristato beveik vien fotografijos mediją ìvairiais būdais apmąstančius ir praplečiančius fotografų ir kitų sričių menininkų kūrinius. Sudarytojo žodyje G. Skudžinskas pateikia daug pasakančią būtent tokio metraščio turinio formavimo motyvaciją:

47 „Paroda Fotografijos grüdas“, in: Kauno fotografijos galerija, [interaktyvus], 20140121 , [žiūrèta 2020-09-28], http://kaunasgallery.lt/naujienos/paroda-fotografijos-grudas.

48 Lietuvos fotografija '17-1, Vilnius: Lietuvos fotomenininkų sajunga, 2017. 
Tikiu, kad atviras žvilgsnis ị dabarti gali akumuliuoti tiek idejjų, tiek raiškos regeneraciją fotografijoje. Gali paskatinti ir savo paties permąstymą, kokybinị lūžĭ, idejjų srautą. Nors reikia pastebėti, kad šis pažadas nebūtinai išsipildys. Kiek tokių galimybių visai neseniai mes jau turèjome? <...> Atrodė, kad išsilaisvinsime iš automatiško spragsẻjimo fotokameromis, kai Vytautas Michelkevičius surengè 3xpozicija parodas, sudarė žurnalo (post)fotografija numerị, ị kritinị kontekstą ịrašè „išplèstinio fotografijos lauko“ savoką. Taip, šie ịvykiai sukėlè šiokių tokių diskusijų, neartikuliuotų permainų nuojautų. Bet pažadas liko neišsipildęs, po nedidelių kivirčų mes grịžome ị patogią kasdienybę, ị ramų ir humanistinị snaudulị. ${ }^{49}$

Nuolatinis siekis permąstyti fotografijos dogmas, priešintis medijos (ir su ja susijusios vyraujančios institucijos) inercijai juntamas ir G. Skudžinsko LFS „Prospekto“ galerijoje kuruojamose lietuvių ir užsienio menininku parodose, leidybos platformoje NoRoutine Books spausdinamose menininkų knygose ${ }^{50}$, taip pat jo asmeninès kūrybos pristatymuose. Iš jo surengtų parodų labiausiai minètinos grupinė paroda $3 D$ vs $2 D$ (2018, „Prospekto“ galerija $)^{51}$ bei jam artimų užsienio menininkų Joachimo Schmido (Vaizdu knyga, 2018, „Prospekto“ galerija) ar Michelio Campeau (Büti analoginejje fotolaboratorijoje su skaitmenine kamera ir skeneriu, 2020, „Prospekto“ galerija, kuratoriai Vilma Samulionytè ir Gytis Skudžinskas) personalinès parodos. G. Skudžinskas per dešimtmetị surengė ir nemažai savo darbu parodų, kurias iš esmès galima suvokti kaip gana nuoseklų pasakojimą apie autoriaus asmeninị (profesinị ir kritinị) santykị su fotografija: Regëjimo pratimai (2012, Kauno fotografijos galerija), Albumas (2014, K. Varnelio namai-muziejus), Kelios fotografijos tiesos (2014, 2016, galerijos „Si:said“, Klaipėda, ir „POST“, Kaunas), 12 fotografijos tiesu (2015, VDA parodų salès „Titanikas“), Dienoraščiai, eskizai, pastabos, citatos ir kitos kasdienybès arba GyS CHAOS (2019, „Prospekto“ galerija).

Pilniausiai ilgalaikę autoriaus poziciją atskleidè paroda 12 fotografijos tiesu, ji sulaukè ir daugiausia reakcijų. A. Narušytè savo apžvalgoje pažymėjo tai, kad fotografijos „tiesų“ demaskavimas ir nostalgiškas atsisveikinimo su fotografija ritualas, kartais virstantis apsėdimu,

49 Gytis Skudžinskas, ,***“, in: Lietuvos fotografija '17-1.

50 NoRoutine Books, [interaktyvus], [žiūrèta 2020-09-28], http://www.nrb.lt.

51 Agnè Narušytè, „Optinis manevras“, in: 7 meno dienos, [interaktyvus], 201809 07, Nr. 27 (1264), [žiūrèta 2020-09-28], http://www.7md.lt/fotografija/2018-09-07/Optinis-manevras. 
Lietuvoje ir pasaulyje vyksta jau ilgą laiką, tačiau paaiškejja, kad vaizdas išlieka, net jei tampa nematomas, o galutinai pribaigti fotografijos niekas nesiryžta, nes tuomet atsiradusią tuštumą reikètų užpildyti kažkuo kitu ${ }^{52}$. Karolina Rybačiauskaitè pabrèžè naują fotografijos veikimo principą ir G. Skudžinsko praktikoje ǐžvelgè ne nihilistinị, o pozityvų pradą:

šiuolaikinè fotografija jau imasi naujos užduoties, būdingos šiuolaikiniam menui: būdama ne mediacijos, o tyrimų ịrankiu, ji vèl nori kurti amžinybę, t. y. siūlo pažinti tikrovę, rasti ryši tarp jos ir savęs. <...> Skudžinsko fotografinio atvaizdo ardymo strategijos ir „laidojimo“ ritualas visai neišreiškia nihilistinio fotografijos medijos neigimo ar tikro siekio su ja atsisveikinti, o parodo, kad fotografija menininkui yra labai įdomus dalykas ir su ja dar daug ką galima nuveikti - net jei ne (at)vaizdų kūrimo būdu. ${ }^{53}$

Vis dèlto Tomas Čiučelis kritiškiausioje parodos recenzijoje iškèlè klausimą:

turint omenyje ištisą savirefleksyvaus konceptualizmo istoriją nuo pat septintojo praeito amžiaus dešimtmečio bei per pastarajji dešimtmetị išsirutuliojusią lietuviškają tos istorijos dalį (pvz., žr. V. Michelkevičiaus kuruotus projektus 3xpozicija.lt, foto/karto/istorio/grafijos, ar net G. Didžiapetrio postfotografinius darbus), čia pat norisi paklausti: ką reiškia vis dar reflektuoti fotografijos galimybės sąlygas šiandien? Ką sako pati tokio reflektavimo praktika? ${ }^{54}$

Teigdamas, kad po daugelio ankstesnių kritinių iniciatyvų fotografija galutinai igijo naują ontologinị postfotografijos statusą, o G. Skudžinsko kūryboje matomas pasikartojantis siekis viešinti fotografinị dogmatizmą pats rizikuoja virsti dogmišku ir formalistiniu anachronizmu, T. Čiučelis daro prielaidą, kad pagrindiniu tokios kritinès strategijos taikiniu gali būti tik LFS, tad nesiliaujantis vidinis dialogas dèl „fotografijos tiesų“ dekonstravimo vyksta beveik išimtinai fotografų bendruomenėje.

52 Agnė Narušytė, „Fotografija (ne) akims“, in: 7 meno dienos, [interaktyvus], 20150220 , Nr. 7 (1113), [žiūrèta 2020-09-28], http://www.7md.lt/daile/2015-02-20/Fotografija-ne-akims.

53 Karolina Rybačiauskaitė, „Trylikta fotografijos tiesa“, in: Literatūra ir menas, [interaktyvus], 201503 06, Nr. 10 (3511), [žiūrèta 2020-09-28], http://literaturairmenas.lt/daile/ karolina-rybaciauskaite-trylikta-fotografijos-tiesa.

54 Tomas Čiučelis, „Valsas su nemirèliu: iki, po, už ir be fotografijos“, in: artnews.lt, [interaktyvus], 201502 03, [žiūrèta 2020-09-28], http://artnews.lt/valsas-su-nemireliu-iki-po-uz-ir-befotografijos-gycio-skudzinsko-paroda-12-fotografijos-tiesu-vda-titanike-27360. 
Apibendrinant pastarujų metų Lietuvos meno raidą galima pastebèti daugiau mažiau nuoseklias postfotografines tendencijas atskirų menininkų kūryboje - be Gyčio Skudžinsko, minètini Darius Vaičekauskas, Akvilè Anglickaitė, Indrė Šerpytytė, Kęstutis Grigaliūnas, Vytenis Jankūnas. Nekonvencionaliais būdais fotografini vaizdą iš naujo kuria tiek meno scenos senbuvis Robertas Narkus (parodoje Valdyba, 2020, galerija „Vartai“), tiek jaunesnès kartos menininkas Vytautas Kumža ${ }^{55}$. Vis dèlto tenka patvirtinti suformuluotą prielaidą, jog minètų postfotografijai svarbių medijos problemų svarstymas vyksta pirmiausia fotografijos institucinès sistemos ir bendruomenės orbitoje arba šalia jos. Net ir tų pačių menininkų pristatymo retorika skirtingose institucijose gali ženkliai skirtis - su šiuolaikiniu menu, o ne su menine fotografija siejamose parodinėse erdvėse heterogeniškos fotografinès formos naudojamos kaip jau ịsisavintos, savaime suprantamos išraiškos priemonès, tarnaujančios kūrinio koncepcijos atskleidimui, o ne konkrečios medijos refleksijai. Pavyzdžiui, ŠMC eksponuotos Malvinos Jelinskaitès (Auksas ir žuvis, 2017) ar Algirdo Šeškaus (TV, 2017) parodos nebuvo akcentuojamos kaip nagrinëjančios savitas fotografinio vaizdo problemas. Išimtis galbūt būtų V. Jankūno paroda Pakeleivis (2015), tačiau ir šiuo atveju reikšmingų diskusijų dèl (post)fotografijos šiuolaikinio meno bendruomenėje nekilo. Šios aplinkybės leidžia teigti esant fotografinio diskurso netolygumą: sąlyginai postfotografinėmis vadintinos individualios praktikos ir grupinès iniciatyvos siekia klibinti jau ne kartą klibintus „tradicinės fotografijos“ pamatus, tačiau toks klibinimas lieka bent formaliai aktualus tik fotografijos sistemos viduje, nes šiuolaikinio meno lauke fotografija nebėra suvokiama kaip problemiška, išskirtinė ar savirefleksijos reikalaujanti medija ${ }^{56}$.

\section{Išvados}

Postfotografijos diskursas ir juo paremtos jaunujų menininkų bei kuratorių iniciatyvos išsivystė kaip atsakas ị idėjinę Lietuvos fotomenininkų sajungos stagnaciją. Šs procesas buvo ne tiek ankstesnių į humanistinės

55 Katažyna Jankovska, „Iliuzijos (ne)apgauna“, in: Literatūra ir menas, [interaktyvus], 202004 16, Nr. 8 (3702), [žiūrèta 2020-09-28], http://iteraturairmenas.lt/index.php/daile/katazynajankovska-iliuzijos-ne-apgauna.

56 Jurij Dobriakov, „Fotografijos laidojimas jūroje“, in: 7 meno dienos, [interaktyvus], 201711 10, Nr. 37 (1231), [žiūrèta 2020-09-28], http://www.7md.lt/fotografija/2017-11-10/Fotografijoslaidojimas-juroje. 
fotografijos paradigmą netelpančių vietinių fotografinių praktikų tąsa, kiek būtent LFS viešpatavimu nepatenkintai jaunajai kartai prieinamų ir aktualių tarptautinių teorinių ir kūrybinių tendencijų ịsisavinimas ir plètojimas. Nors siekis išplèsti fotografijos sampratos ribas buvo nukreiptas ị šios medijos įtraukimą i bendrą šiuolaikinio meno diskursą, pagrindinès diskusijos vyko ne pastarajame, o fotografijos srityje, nes šiuolaikinio meno bendruomenei nebuvo artimas susitelkimas i atskirų medijų problemas. Postfotografinio judėjimo šalininkų ir jo komentatorių siūlomi postfotografijos sampratos apibrèžimai buvo skirtingi ir neretai itin atviri, tačiau daugumą jų vienijo dèmesio sutelkimas ị teorini diskursą, koncepciją ir fotografijos medialumą, o ne vaizdo turinị. Tokị susidomėjimą medijos savybėmis didele dalimi lèmè tai, kad postfotografijos šalininkai tuo pat metu buvo aktyvūs ir naujujų medijų kultūros lauke.

Lietuvoje nuslopus tiek naujujų medijų meno, tiek postfotografijos diskursams, o jų vystytojams perëjus i postmedialų šiuolaikinio meno lauką, po 2010 m. naujausias „lūžines“ tendencijas fotografijoje kūrè jau kita karta. Postfotografijos sajūdžio ji nelaikè savo idėjiniu pirmtaku, nesvarstè jo reikšmès ir sutelkè dėmesị i kitas, svarbias „interneto kartai“, filosofines ir estetines problemas. Toks ankstesnių procesų nepaisymas ịvairių kartų kritikus paskatino vèl prisiminti postfotografijos sajūdị ir apsvarstyti tolesnę jo šalininkų kūrybinės veiklos raidą, ši reiškinị paverčiant iš esmès istoriniu, aktualioje tikrovėje nebevykstančiu. Tačiau, be naujus poslinkius skelbusių jaunųjų kūrẻjų, dalis anksčiau karjerą pradejusių menininkų iš esmès tebetaikè postfotografines prieigas savo asmeninei praktikai, nors ir nebesudarè daugiau mažiau matomo judèjimo. Visgi tokio pasikartojančio fotografijos klišių ir mitų dekonstravimo tikslingumu XXI a. 2-ojo dešimtmečio viduryje imta vis labiau abejoti.

Šiuolaikinio meno institucijos fotografiją visiškai ịsisavino kaip vieną iš daugelio naudojamų medijų, nereikalaujančią jokio išskirtinio statuso. Galima teigti, kad tai ịvyko žinant postfotografines diskusijas fotografų bendruomenėje ir šalia jos, tačiau atsižvelgiant i visai kitus, šiuolaikinio meno postmedialiai perspektyvai priimtinesnius motyvus. XXI a. 2-3-iojo dešimtmečių sankirtoje ịsigali fotografinių paradigmų pliuralizmas - nuo 
vis dar gyvuojančio humanistinio estetizuoto požiūrio iki tebesikartojančiu pastangų demitologizuoti fotografiją ar fotografinio atvaizdo kaip paprasčiausio srautinės ir vis labiau automatizuotos vizualinès kultūros fakto suvokimo. Kartais tarp šių paradigmų atsiranda sąlyčio taškų, tačiau bendraja prasme dabartinė Lietuvos fotografijos savivoka yra netolygi.

Todèl galima teigti, kad postfotografijos sajūdis Lietuvoje ne tiek pakeitė fotografijos suvokimą ir kanoną iš esmès, kiek pasiūlè kitą požiūrị, kuris atspindejjo to meto teorines ir sociokultūrines aktualijas bei paveikè kūrybinę atskirų menininkų praktiką, nors kartu paradoksaliai tarsi uždarè šiuos autorius fotografijos, o ne šiuolaikinio meno lauke. Praėjus beveik penkiolikai metų po jo iškilimo tebegyvuoja įvairios fotografijos, o postfotografiją galima suvokti kaip ryškų, tačiau trumpalaikị blyksnį, kurio reikejjo fotografijos bendruomenès savivokos permąstymui ir atsinaujinimui, tačiau šiuolaikinio meno diskursa, ỉ kuri pirmiausia taikè, postfotografijos idèjos paveikè daug mažiau.

Gauta -20201127 


\section{Literatūra}

[re:] Fotografija, 2007, Nr. 2 (15), sud. Margarita Matulytè.

Bajarkevičius Tautvydas, „Apie postfotografiją“, in: 7 meno dienos, [interaktyvus], 200611 10, Nr. 730, [žiūrèta 2020-09-28], http://www.7md.lt/archyvas.php?leid_ $\mathrm{id}=730 \&$ str_id $=6507$.

Baker George, „Photography's Expanded Field“, in: October, 114, 2005, p. 120-140.

Batchen Geoffrey, „On Post-photography“, in: Afterimage, 1992, t. 20, Nr. 3, p. 17.

Bishop Claire, „Digital Divide: Contemporary Art and New Media“, in: Artforum, 2012 rugsèjis, t. 51, Nr. 1.

Cornell Lauren, Droitcour Brian, „Technical Difficulties“, in: Artforum, 2013 sausis, t. 51, Nr. 5 .

Čiučelis Tomas, „Valsas su nemirèliu: iki, po, už ir be fotografijos", in: artnews.lt, [interaktyvus], 201502 03, [žiūrèta 2020-09-28], http://artnews.lt/valsas-su-nemireliu-iki-po-uz-ir-be-fotografijos-gycio-skudzinsko-paroda-12-fotografijos-tiesu-vda-titanike-27360.

Dobriakov Jurij, „(Vis deltto,) kas yra Lietuvos šiuolaikinė fotografija?“, in: artnews.lt, [interaktyvus], 201402 01, [žiūrèta 2020-0928], http://artnews.lt/vis-delto-kas-yra-lietuvos-siuolaikine-fotografija-22553.

Dobriakov Jurij, „Fotografijos laidojimas jūroje“, in: 7 meno dienos, [interaktyvus], 2017 11 10, Nr. 37 (1231), [žiūrèta 2020-09-28], http://www.7md.lt/fotografija/2017-11-10/ Fotografijos-laidojimas-juroje.

Dobriakov Jurij, Narušytė Agnė, „Kas nutiko lietuviškam medijų menui?", in: 7 meno dienos, [interaktyvus], 201511 20, Nr. 41 (1147), [žiūrèta 2020-09-28], http://www.7md.lt/tarp_disciplinu/2015-11-20/Kas-nutiko-lietuviskam-mediju-menui.

Fomina Julija, Klimašauskas Valentinas, „Kai vaizdas tampa pokalbiu“, in: Interviu, 2008, Nr. 11/12, p. 38-39.

Fotografija, 2008, Nr. 1-2 (16-17), sud. Julija Fomina ir Valentinas Klimašauskas.
Grendaitė Greta, „Pozicija: kritiškas konceptualumas“, in: Nemunas, 200701 25, Nr. 4 (138-579), p. 2, 14.

„Ieškant „post“ fotografijoje ir svarstant, kas galètų būti po šiuolaikinio meno“, in Postfotografija, 2006, Nr. (13), sud. Vytautas Michelkevičius, p. 16-23.

„Išplèstinis fotografijos laukas ir fotografijos institucijos šiuolaikinio meno scenoje“, in: Postfotografija, 2006, Nr. 2 (13), sud. Vytautas Michelkevičius, p. 40-50.

Jankovska Katažyna, „Iliuzijos (ne)apgauna“, in: Literatūra ir menas, [interaktyvus], 202004 16, Nr. 8 (3702), [žiūrèta 2020-0928], http://iteraturairmenas.lt/index.php/ daile/katazyna-jankovska-iliuzijos-ne-apgauna.

Klimašauskas Valentinas, „Fotografijos nuotykiai išplèstuose laukuose“, in: [re:] Fotografija, 2007, Nr. 1 (14), sud. Margarita Matulytè, p. 4-7.

Krikštopaitytė Monika, „Šsis bei tas“, in: 7 meno dienos, [interaktyvus], 200703 02, Nr. 745, [žiūrèta 2020-09-28], http://www.7md.lt/ archyvas.php?leid_id $=745 \&$ str_id $=6901$.

Krivickas Povilas Sigitas, „Ar postfotografijos karalius neliks nuogas?“, in: Nemunas, 2006 12 14, Nr. 44 (132-573), p. 12-13.

Lietuvos fotografija '17-1, Vilnius: Lietuvos fotomenininkų sajunga, 2017.

Macijauskas Aleksandras, „Ar jaunieji žino, ką griauna?“, in: Nemunas, 200701 04, Nr. 1 (135-576), p. 3.

Michelkevičè Lina, Michelkevičius Vytautas, „Unwritten Histories of Extinct Media Art in Lithuania: From the 2000s of Great Promise to the Multidirectional 2010s“, in: Acoustic Space, t. 15, Riga: RIXC Center for New Media Culture and Liepaja: Art Research Lab (MPLab) of Liepaja University, 2016, p. 70-83.

Michelkevičius Vytautas, Gidas po postfotografijos teritorija internete ir galerijoje, Vilnius: VšI Mene, 2006.

Michelkevičius Vytautas, „Komunikacijos malonumai, arba Ką gali mano mobilusis telefonas“, in: Durys, 200611 29, Nr. 138, p. 10 . 
Michelkevičius Vytautas, „Konceptualizmas išgelbėjo fotografiją: komentarų komentarai“, in: Nemunas, 200702 08, Nr. 6 (140-581), p. 14.

Michelkevičius Vytautas, „Smalsumas ir ieškojimai“, in: Postfotografija, 2006, Nr. 2 (13), sud. Vytautas Michelkevičius, p. 2-3.

Mitchell William J., The Reconfigured Eye: Visual Truth in the Post-Photographic Era, Cambridge, Mass.: MIT Press, 1992.

Narušytė Agnè, „Fotografija (ne) akims“, in: 7 meno dienos, [interaktyvus], 201502 20, Nr. 7 (1113), [žiūrèta 2020-09-28], http:// www.7md.lt/daile/2015-02-20/Fotografija-ne-akims.

Narušytė Agnè, Lietuvos fotografija: 19902010, Vilnius: Baltos lankos, 2011.

Narušytė Agnė, „Optinis manevras“, in: 7 meno dienos, [interaktyvus], 20180907 , Nr. 27 (1264), [žiūrèta 2020-09-28], http:// www.7md.lt/fotografija/2018-09-07/Optinis-manevras.

Narušytė Agnè, „Postfotografijos pėdsakas Lietuvoje: pasižvalgymai po vietinį kontekstą“, in: Postfotografija, 2006, Nr. 2 (13), sud. Vytautas Michelkevičius, p. 4-12.

Narušytė Agnè, ,Tarsi nebūtų fotografijos“, in: 7 meno dienos, [interaktyvus], 20140401 , Nr. 14 (1075), [žiūrèta 2020-09-28], http:// www.7md.lt/fotografija/2014-04-11/Tarsi-nebutu-fotografijos.

Narušytė Agnè, „Testas fotografijos laukui“, in: 7 meno dienos, [interaktyvus], 201404 18, Nr. 15 (1076), [žiūrèta 2020-09-28], http:// www.7md.lt/daile/2014-04-18/Testas-fotografijos-laukui.

Pabedinskas Tomas, „Karalius nuogas!“, in: Nemunas, 200701 18, Nr. 3 (137-578), p. 4.

„Parodos uždarymas ir diskusija ,Komentarai fotografijai ir tarpdiscipliniškumui““, in: 3xposition.lt, [interaktyvus], 20061108 , [žiūrèta 2020-09-28], http://www.3xposition. $\mathrm{lt} / \mathrm{p}=121$.

„Paskaitų ir pokalbių ciklas Kas nèra fotografija Nacionalinèje dailès galerijoje“, in: Kita fotografija, [interaktyvus], 201403 31, [žiūrèta 2020-09-28], http://web.archive.org/ web/20150602235334/http://www.kitafotografija.lt/paskaitu-ir-pokalbiu-ciklas-kas-nera-fotografija-nacionalineje-dailes-galerijoje-5702.

Petraitis Paulius, „XXI a. reprezentuoja XX a. viziją? Lietuvos fotografijos metraščiai“, in: Kultūros barai, 2012, Nr. 1, p. 45-48.

Photography After Photography: Memory and Representation in the Digital Age, eds. Stefan Iglhaut et al., Amsterdam: Overseas Publishers Association, 1996.

Požerskis Romualdas, ,Visi post- yra konceptualizmas“, in: Nemunas, 200701 11, Nr. 2 (136-577), p. 11.

Rybačiauskaitė Karolina, „Trylikta fotografijos tiesa“, in: Literatūra ir menas, [interaktyvus], 201503 06, Nr. 10 (3511), [žiūrèta 2020-09-28], http://literaturairmenas.lt/ daile/karolina-rybaciauskaite-trylikta-fotografijos-tiesa.

Skudžinskas Gytis, „,Erozija‘: 325 dienos su fotografija“, in: Durys, 200611 29, Nr. 138, p. 7 .

Skudžinskas Gytis, „***“, in: Lietuvos fotografija '17-1, Vilnius: Lietuvos fotomenininku sajunga, 2017.

„Tarsi nebūtų rytojaus - interneto kartos žinutè tarp dviejų viršelių“, in: Kita fotografija, [interaktyvus], 20140124 , [žiūrèta 2020-09-28], http://web.archive. org/web/20160412122309/http://www. kitafotografija.lt/tarsi-nebutu-rytojaus-interneto-kartos-zinute-tarp-dvieju-virseliu-interviu-su-juste-jonutyte-ir-pauliumi-petraiciu-5293.

Tarsi nebūtu rytojaus. Jaunosios kartos Lietuvos fotografija, sud. Justè Jonutytè ir Paulius Petraitis, Vilnius: Rupert, 2013.

Tomas David, „From the Photograph to Postphotographic Practice: Toward a Postoptical Ecology of the Eye“, in: SubStance, 1988, t. 17 , Nr. 1 (55), p. 59-68.

Vietos karta: atvaizdas, atmintis ir fikcija Baltijos šalyse, sud. Vytautas Michelkevičius, Vilnius: VšI Mene, 2011. 


\title{
Summary
}

\section{Postphotography: A Dead-End or an Intermediate Stage in the Evolution of Lithuanian Photography?}

\author{
Jurij Dobriakov
}

Keywords: postphotography, expanded photography, contemporary photography, media art, contemporary art.

The year 2006 saw a new term emerge and take root quite rapidly in the Lithuanian photography and contemporary art field, triggering a heated debate (primarily between younger-generation artists and curators and some members of the Union of Lithuanian Art Photographers): postphotography. This term and phenomenon, imported from the international discourse, first materialised in an exhibition titled comments@3xposition.lt, publicly co-curated by a group of fellow-minded artists and theorists at the Union's head gallery in Vilnius, and the accompanying events and publications. The polemic on the prospects of postphotography unfolded in the Lithuanian cultural press for approximately two more years, until 2008.

Although there were multiple attempts to define postphotography at the time, what all of them had in common was an emphasis on the necessity of comprehending photography as a medium, a discursive system of communication and distribution, and a platform for the production of meaning. Thus, the postphotographic movement inevitably adopted a critical and deconstructivist perspective on (art) photography as an institutionalised system, and essentially commented on the latter, seeking to expose its entrenched dogmas and expand the limits of photographic expression and discourse. The movement was closely allied with the field of new media culture and art, predominantly fostered by some of the same artists, curators, and researchers. Both scenes waned in Lithuania by the early 2010s, when the interest in the media discourse declined, and most of their key players settled in the postmedial 
contemporary art field and distanced themselves from the discourses associated with particular historical art forms, as well as critical deconstruction of the latter. Although one of the aims of the postphotography movement was to integrate photography in the spectrum of the means of expression employed by contemporary art, the latter more or less independently assimilated it as merely one of the different media used to express a concept or a phenomenon of mass visual culture, without taking into account its specific history as an art form and its medial qualities (unlike the postphotographic paradigm).

After 2010, the concept of postphotography has been emerging in Lithuanian reflections on photography and the broader visual culture only in retrospect, as a historical phenomenon without an active discourse. Nevertheless, postphotographic strategies can still be identified in the individual practices of artists more or less gravitating towards the photographic community, yet some commentators have voiced concern that such work fails to produce a qualitatively new critical gesture. Meanwhile, in the context of contemporary art, artists continue to actively explore the circulation of photographic images in the expanded cultural field, yet the ideological premises of such exploration have changed. Artists have become more preoccupied with 'posthuman' phenomena like machine vision, anonymous circulation of images online and offline, such images as data compounds, and algorithmic photography, as opposed to the deconstruction of photographic conventions. Hence, more recent artistic endeavours focused on the image do not take postphotography as their inspiration or point of reference.

The article aims to discuss the legacy of the Lithuanian postphotographic discourse and its input into the development of the photography and contemporary art fields, as well as to determine the extent of its impact. 